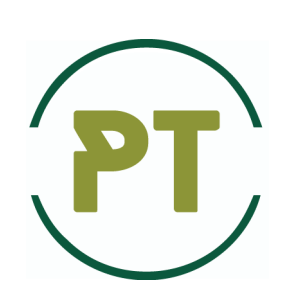

Problems of Tribology, V. 25, No 3/97-2020, 14-18

Problems of Tribology

Website: http://tribology.khnu.km.ua/index.php/ProbTrib

E-mail: tribosenator@gmail.com

DOI: https://doi.org/10.31891/2079-1372-2020-97-3-14-18

\title{
Infuence of fiber vniivlon on the performance of organoplastics based on the BSP-7 copolymer
}

\author{
O.I. Burya, M.O. Grashchenkova*, O.B. Lysenko, Ye.A. Yeriomina \\ Dniprovsk State Technical University, Ukraine \\ EE-mail: marina_gr@i.ua
}

\begin{abstract}
This paper focuses on tribotechnical and physical-mechanical properties of the BSP-7 copolymer and organoplastics based on it with $10 \div 40$ mass $\%$ of polyheteroarylene vniivlon fiber. It demonstrates that the reinforcement of copolymer with organic fiber improves its abrasive wear resistance by $64,2 \%$ at a maximum filler content of 30 mass $\%$.

Proposed organoplastics based on the BSP-7 copolymer with effective content of 30 mass \% of the filler can be recommended as a tribotechnical material for the manufacturing of the parts that work in the conditions of abrasive wear.
\end{abstract}

Key words: copolymer, fiber, vniivlon, organoplastic, abrasive wear resistance.

\section{Introduction}

Abrasive wear of materials is one of the most widespread in practice types of wear to which the parts of agricultural, road-building, mining, transport machines, friction units of metallurgical equipment, etc are exposed. The intensity of abrasive wear is influenced by the nature of abrasive particles, aggressiveness of the environment, physical-mechanical properties of wear surfaces, shock interaction, temperature and other factors.

The development of new polymer composite materials (PCM) capable of operating at machine friction units and mechanisms of variouspurposeunder specified operating conditions taking into account the nature of the impact of abrasive particles on the workpiece is an effective solution to the problem of increase in wear resistance and reliability of the parts [1 - 3].

\section{Literature review}

PCM based on thermoplastic binders that are characterized by high tribotechnical properties, fabricability, reliability, and relatively low cost are successfully used in modern friction units [4].

The use of thermoplastic Sulfuryl BSP-7copolymer [5] as a binder is perspective enough, because by its complex of operational properties it surpasses such known serial materials as B caprolon (TU 6-05-988-1987), PA 6 210/310 polyamide (OST 6-06-S9-1993), 12-L polyamide (OST 6-06-425-1992). These materials are structural antifriction materials of which are made bushings, rings, inserts and other parts of mobile joints, operating in conditions of abrasive wear without lubrication. The reinforcement of the binder with discrete chemical fibers helps to improve performance of thermoplastic polymers significantly [6].

\section{Purpose}

The goal of the work was to increase the abrasion resistance of PCM based on theBSP-7copolymer, by way of reinforcing the binder with organic fiber vniivlon, for the predicted increase in the life of parts of machines and mechanisms.

\section{Methods}

The object of the study was Sulfaryl BSP-7 copolymer and organoplastics (OP) based on it, reinforced with organic polyheteroarylene vniivlon fiber (density is $1,43 \mathrm{~g} / \mathrm{cm}^{3}$, tensile strength is $4,5 \times 10^{3} \mathrm{MPa}$, tensile 
strain is $3,9 \%$, elastic modulus is $150 \times 10^{3} \mathrm{MPa}$ ) [7]. The content of the fiber in these compositions was $10 \div 40$ mass $\%$. The reinforcement of the binder with the fiber was made in rotating electromagnetic field using ferromagnetic particles [8]. The samples were made by the method of compression moulding using the following technology:

- tableting at room temperature at a pressure of $6 \mathrm{MPa}$;

- drying blanks for 90 minutes at a temperature of $393 \mathrm{~K}$;

- loading blanks in the mold heated to the temperature of $443 \mathrm{~K}$;

- rising temperature up to $538 \mathrm{~K}$ and exposing the blanks without pressure during 5 minutes, 5 minutes at a pressure of $5 \mathrm{MPa}$;

- pressing the samples at a temperature of $443 \mathrm{~K}$;

- mechanical restoration (flash removal).

The research on abrasive wear of OP was carried out according to GOST (State Standard) 11012-2017 using Hecker machine in the conditions of friction over fixed abrasive particles (coated abrasive with dispersity of $40 \div 60 \mu \mathrm{m}$ ). The value of reduce in sample volume in $\mathrm{mm} 3$ on $1 \mathrm{~m}$ of path was taken as the detrition index $\left(V_{i}\right)$. It was calculated using the formula:

$$
V_{i}=\frac{\Delta m}{\rho \cdot L},
$$

where $\Delta m$ is the value of mass wear, $\mathrm{g}$;

$\rho$ is the density of material, $\mathrm{g} / \mathrm{cm}^{3}$;

$L$ is the length of detrition path, $\mathrm{m}$.

The density of OP $(\rho)$ was determined by hydrostatic method (GOST 15139-69). Friction surface of the samples was studied using BIOLAM-M microscope at a magnification of 180 .

The main property that influences abrasive wear resistance most of all is the hardness of materials. This study determines the hardness of OP according to Rockwell (L scale, the diameter of ball was 6,35 mm, general load was 588,4 N) using 2074 TPR hardometer according to GOST 24622-91. The measurement of microhardness of OP was carried out in cross and longitudinal sections according to Vickers using PMT-3M microhardometer (GOST 9450-76).

\section{Results}

The degree of filling of composite materials with fiber is determined by the melt viscosity, the total surface area of the filler particles, and the ir surface energy. It is known that as the fiber content increases the strength of the filled polymer increases to a certain level, after which there is a slowdown in the growth of indicators, or even their decline. The optimum degree of filling with organic fiber for most thermoplastics is $25 \div 30$ mass $\%$. When the fiber content is more than 30 mass \% polymer melt viscosity increases rapidly, the fiber is crushed in the molding process, the thin film of the polymer does not with stand the stresses caused by the difference in the thermoplastic properties of the binder and the filler. This leads to a deterioration of the physical and mechanical properties of the composite material [9].

Taking in to account the above, the content of polyheteroarylene vniivlon fiber in the investigated compositions was $10 \div 40$ mass $\%$.

Hardness is traditionally used to evaluate the level of mechanical properties of materials. Hardness is a characteristic that serves as the most obvious indicator of the manifestation of hardening and allows to indirectly evaluate the mechanical characteristics of the material, such as the level of strength, without conducting additional studies.

When rubbing on fixed abrasive particles in many cases with increasing hardness of the material, its wear resistance increases [10].

The results of the research of organoplastics are presented in the Fig. 1.

It is shown that as the fiber content of the polymer binder increases, the abrasive wear ratio of $\mathrm{Vi}$ decreases (curve 1) and takes a minimum value of $30 \mathrm{wt}$. \%. Thus, Vi for unreinforced copolymer is $2,4 \mathrm{~mm}^{3} / \mathrm{m}$, and changes from 1,4 to $0,86 \mathrm{~mm}^{3} / \mathrm{m}$ for OP. That is, abrasive wear indicator can be reduced 2,8 times for OP in comparison with the BSP-7copolymer due to reinforcing effect of fibrous filler. This result is due to the strengthening of binder under the influence of the harder surface of filler. Also it is confirmed by the improvement of hardness HRL (curve 2) for OP from 102 to 113,5 (1,1 times).

Further increase in the content of the filler leads to a deterioration of Vi and HRL, which can be explained by the loosening of the fiber and the formation of non-impregnated binder sites on the border of "polymer-fiber" during the processing of the OP.

The hardening effect is determined by the wetting and subsequent adhesion of the fibrous filler to the matrix polymer. In this case, an interfacial layer with high ordering and limited conformation of macromolecules is formed, which contributes to the formation of a fine crystal structure of the polymer and reduces the probability of occurrence of defects, which are foci of destruction [11]. 


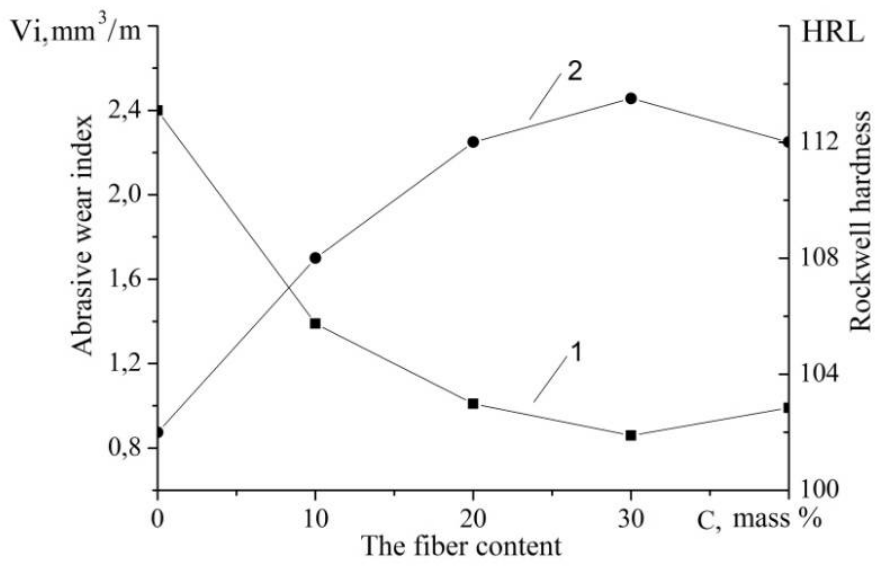

Fig. 1. The influence of Vniivlon fiber percentage on the indicator of abrasive wear (Vi) (1)

and Rockwell hardness (HRL) (2) of organoplastics based on the BSP-7 copolymer

The change in the structure of the BSP-7 copolymer under the influence of the filler is confirmed by the results of measurements of microhardness (HV) of composite materials (Fig. 2).

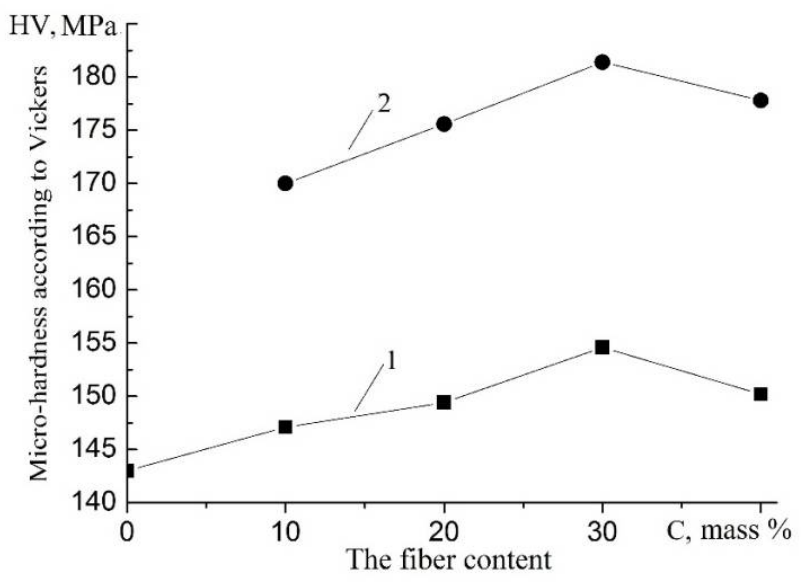

Fig. 2. The relationship of micro-hardness (HV) of polymer matrix (1) and the boundary of separation of "polymer-fiber" (2) organoplastics based on the BSP-7copolymer containing fiber

The graph shows that the values of micro-hardness on the "polymer-binder" division boundary (curve 2) are higher in comparison with matrix (curve 1). This indicates good impregnation of the filler with polymer binder. With the increase of fiber to 30 mass \% there is gradualin crease of HV value on both curves: from 143 to $154,6 \mathrm{MPa}$ for matrix, from 170 to181,4MPa on the "polymer-binder" division boundary. Taking that into account, we can talk about the strengthening of the polymer matrix and the even distribution of the filler in its volume. After that, a slight drop in curves and the reduction in micro-hardness of OP respectively are observed. That is due to the deterioration of adhesion between binder and fiber.

To explain the nature of the relationship between micro-hardness and composition, the effect of filler contenton the hydrostatic density ( $\rho_{\text {hyd. }}$ ) of OP was studied (Fig. 3).

As can be seen from the graphs shown in Fig. 3, when the degree of filling is $10 \div 30$ mass $\% \rho_{\text {hyd. }}$ (curve 1) has higher values than $\rho_{\text {ad. }}$ (curve 2 ). That confirms the quality permeation of the fiber with binder. With further increase in amount of the filler up to 40 mass $\%$, the value of $\rho_{\text {hyd. }}$ decreases and becomes lower than $\rho_{\text {ad. }}$, which can be explained by the deterioration of adhesion in the polymer-fiber boundary layer and the formation of micro-voids. occurs.

In general, a good correlation between the tribotechnical and physical-mechanical properties of PCM

A visual analysis of the friction surfaces of the OP (Fig. 4) revealed the presence of the following types of frictional destruction [12]. 


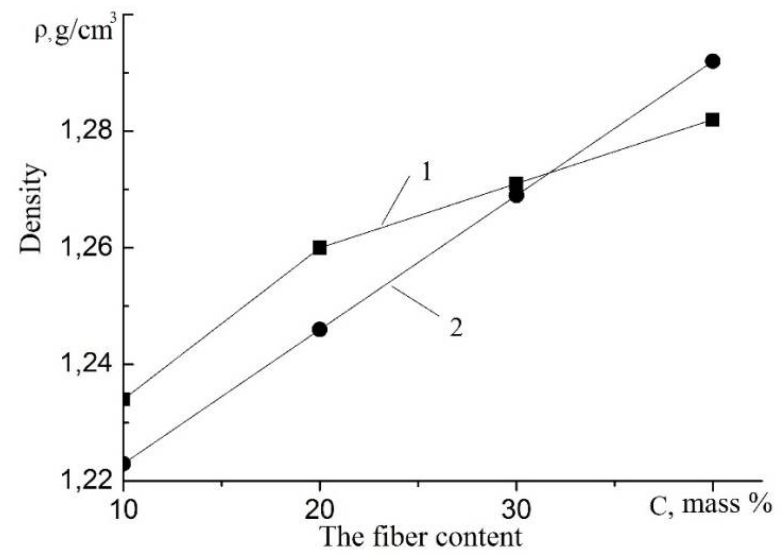

Fig. 3. Influence of vniivlon fiber percentage on the hydrostatic $\rho_{\text {hyd. }}(1)$ and additive $\rho_{\text {ad. }}$ (2) density of organoplastics based on the BSP-7 copolymer

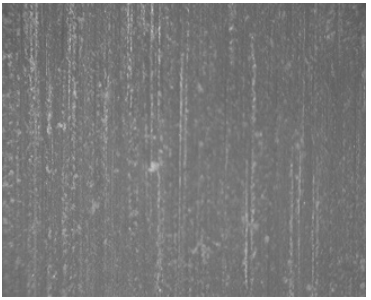

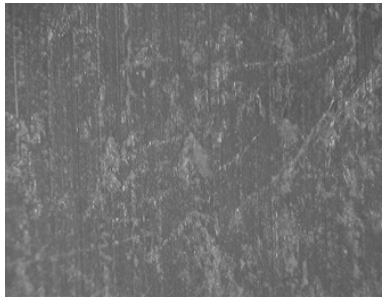

b

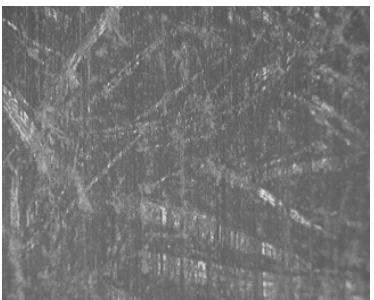

c

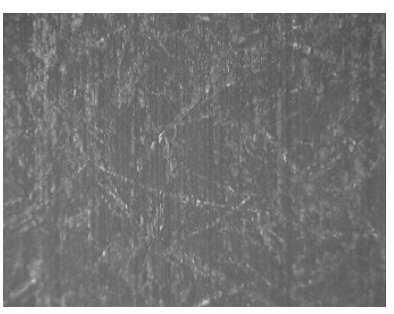

d

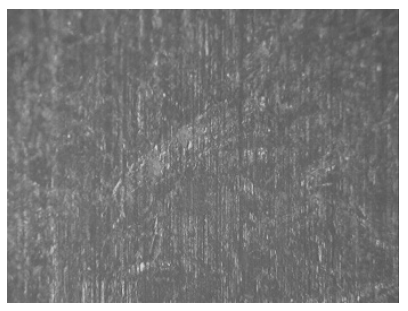

e

Fig. 4. The structure $(\times 180)$ of friction surfaces of the samples of the BSP-7 copolymer (a) and organoplastics on its base with the content of vniivlon fiber of 10 mass\% (b), 20 mass \% (c), 30 mass \% (d), 40 mass \% (e)

When the fiber content is 10 mass \% (Fig. 4, b) microprojection of the sample surface with furrow formation is observed; when the fillingis $20 \div 30$ mass \% (Fig. 4, c, d) the furrow depth decreases, which in dicates the strengthening of the polymer matrix and increase the wear resistance of the PCM due to there in forcing effect. When the fiber content is 40 mass \% (Fig. 4, e) the number and depth of micropricesare slightly increasing. By the nature of the destruction of the friction surface of the specimens, we can conclude that the wear occurred by the micro-cutting mechanism. Also, note the uniform distribution of the fiber in the volume of the polymer matrix. Likewise, uniform distribution of the fiber in the volume of the polymer matrix should be noted.

\section{Conclusions}

According to the results of PCM studies on the basis of the BPS-7 copolymer, it is established that the introduction of vniivlon fiber in the amount of $30 \mathrm{wt} . \%$ leads to an increase in abrasive wear resistanceby 64,2 $\%$ relative to the properties of the original polymer.

The improvement of tribotechnical and physical-mechanical characteristics of the proposed OPs indicates the feasibility of their use as wear-resistant materials for the manufacture of parts operating in abrasive wear conditions. 


\section{References}

1. Kabat, O. S. (2019). Polymeric composites of tribotechnical purpose based on fluoropolymers. Problems of Tribology, Vol. 24, 2/92, $75-81$.

2. Masiuk A. S. (2017). Polikaproamidni kompozyty z pidvyshchennymy ekspluatatsiinymy kharakterystykamy [Polycaproamide composites with high performance characteristics]. Naukoviy visnyk NLTU Ukrainy: zbirnyk nauk. prats - Scientific Bulletin of NLTU of Ukraine: a collection of scientific works, Vol. 27, 4, $122-126$.

3.Chyhvintseva O. P., Rula I.V., Tokar A.V., Kravchenko S.V., Petrushyna H.A. (2018). Vyvchennia vlastyvostei vuhleplastyka na osnovi fenilona S-2 [Study of the properties of carbon fiber based on phenylone C2]. Naukovi notatky: mizhvuz. sb. - Scientific Notes: interuniversity collection, Vol. 64, 236-242.

4. Burya O.I. (2019). Polimerni kompozyty na osnovi termoplastychnykh viazhuchykh [Polymer composites based on thermoplastic binders]. Dnipro: Seredniak T. K.

5. Shustov G.B., Burya A.I., Dubkova V.I., Ermolenko I.N. (1990). Sintez i svoystva poliarilatsulfonovogo blok-sopolimera i kompozitov na ego osnove [Synthesis and properties of polyarylatesulfonic block copolymer and composites based on it]. Zhurnal Dokladyi AN BSSR - J. Reports of the Academy of Sciences of the BSSR. Minsk: Navuka i tehnIka, Vol. XXXIV, 12, 1104-1106.

6. Burya A.I., Naberezhanaya O.A., Schetinin A.M. (2014). Vliyanie soderzhaniya volokna sulfon-T na tribologicheskie svoystva organoplastikov na osnove fenilona S-1 [Influence of sulfon-T fiber content on tribological properties of phenylone C-1-based organoplastics]. Dizayn. Materialyi. Tehnologiya - Design. Materials. Technology, $104-107$.

7. Buria O.I. Pat. 101213 Ukraina, MPK S08L 69/00.Polimernakompozytsiia / Buria O. I., Shustov H. B., Grashchenkova M. O.; Zaiavnyk ta patentovlasnyk: Buria O. I. - № u 2015 03390; zaiav. 10.04.15; opubl. 25.08.15; Biul. №16.

8. Burya A.I., Pilipenko A.I., Ryibak T.I. (1995). Razrabotka sposoba polucheniya i issledovanie svoystv armirovannyih plastikov [Development of a method for obtaining and studying the properties of reinforced plastics]. Nowe kierunki modyfikacji i zastosowan tworzyw sztucznych: VI Konferencja Naukowo-Techiczna. Rydzyna, 44-53.

9. Trostyanskaya E.B. (1975). Termoplastyi konstruktsionnogo naznacheniya [Thermoplastics for structural purposes]. Moskva: Himiya.

10. Dobrovolskiy A. G., Koshelenko P.I. (1989). Abrazivnaya iznosostoykost materialov [ Abrasive wear resistance of materials]. Kiey: Tehnika.

11. Tugov I. I., Kostryikina G. I. (1989). Himiya i fizika polimerov [Chemistry and physics of polymers]. Moscva: Himiya.

12. Belyiy V.A., Sviridenok A.I., Petrokovets M.I., Savkin V.G. (1976). Trenie i iznos materialov na osnove polimerov [Friction and wear of polymer-based materials]. Minsk: Nauka i tehnika.

Буря О.І., Гращенкова М.О., Лисенко О.Б., Срьоміна К.А. Вплив волокна вніівлон на експлуатаційні характеристики органопластиків на основі кополімеру БСП-7.

Розробка нових полімерних композиційних матеріалів, здатних працювати у вузлах тертя машин та механізмів різного призначення при заданих умовах експлуатації, з урахуванням характеру впливу абразивних часток на деталь $є$ ефективним рішенням проблеми підвищення зносостійкості та надійності деталей.

В роботі представлені композиційні матеріали на основі термопластичного кополімеру БСП-7 та полігетероариленового волокна вніівлон з вмістом наповнювача $10 \div 40$ мас. \%, які отримували методом компресійного пресування. Проведені дослідження композитів на абразивне зношування в умовах тертя по нерухомо закріпленим абразивним часткам. Здійсненні вимірювання твердості за Роквеллом (шкала L) та мікротвердості за Віккерсом. Досліджено структуру поверхні зразків після тертя.

За результатами досліджень встановлено, що при вмісті волокна 30 мас. \% абразивна зносостійкість збільшується на 64,2 \%. Даний результат обумовлений зміцненням структури в'яжучогопід впливом більш твердої поверхні наповнювача. Значення мікротвердості органопластиків показали добру адгезію між волокном та полімерним в'яжучим при наповнені $10 \div 30$ мас. \%, що додатково підтверджено результатами вимірювання гідростатичної густини органопластиків. За характером руйнування поверхні тертя зразків визначено, що зношування відбувалося за механізмом мікрорізання.

В цілому, триботехнічні характеристики розроблених композиційних матеріалів добре корелюють з їх фізико-механічними показниками.

Ключові слова: кополімер, волокно, вніівлон, органопластик, абразивна зносостійкість. 